\title{
FÖRINTELSELITTERATUREN OCH ANDRA GENERATIONENS ÖVERLEVANDE
}

\author{
Anders Ohlsson \\ Växjö Universitet \\ $-\infty-$
}

\section{BAKGRUND OCH SYFTE}

Att vi som människor påverkas av mer eller mindre traumatiska upplevelser $\mathrm{i}$ det förflutna är en truism i vår kultur. För Förintelsens överlevande offer är detta snart sagt dagligen en realitet, vilket inte minst litteraturen om denna händelse bär talrika vittnesbörd om. Men den tyska naziregimens brott mot det judiska folket sätter dessutom i allra högsta grad sin prägel på livsvillkoren för de barn vars ena förälder eller eventuellt båda överlevde Förintelsen. Till denna den så kallade "andra generationen" brukar man räkna de "vars föräldrar överlevt de tyska koncentrationslägren, samt alla de, vars föräldrar tvingades fly, gömma sig eller leva under falsk identitet för att klara sig undan nazisternas judeförföljelser”. ' Ett pionjärarbete när det gäller de speciella erfarenheterna bland dessa barn till Förintelsens överlevande offer är Helen Epsteins Children of the Holocaust. Conversations with Sons and Daughters of Survivors (1979). Epstein är amerikansk journalist, tillhör själv andra generationens överlevande och i slutet av 1970-talet bröt hon tystnaden som omgav denna grupp genom att söka upp och intervjua personer som delade hennes egna erfarenheter.

Förintelselitteraturen - memoarer, självbiografier, romaner, noveller och lyrik om den tyska naziregimens brott mot det judiska folket - rymmer också bidrag av de överlevande offrens barn. En översikt över amerikanska texter skrivna av den andra generationens överlevande finns i Alan L. Bergers studie Children of Job. American Second-Generation Witnesses to the Holocaust (I997). Av naturliga skäl dröjde det, som Berger framhåller, en bit in på r98o-talet 
innan denna grupp började publicera sig med någorlunda regelbundenhet. ${ }^{2}$ Ett välkänt amerikanskt exempel är Art Spiegelmans Maus: a Survivors Story; del I utkom 1986 och del II r99I. Här berättar en karaktär, som är namne med den verklige författaren, i serieteckningens form, om faderns erfarenheter från Förintelsen och om dess återverkningar i sitt eget liv.

För den andra generationens överlevande gäller, som Berger med en pregnant formulering uttrycker det, att de "attest to an event that they never lived through but that ineluctably shapes their lives". ${ }^{3}$ De kallas ibland "Jobs barn", eftersom de i likhet med de tio barn Gamla testamentets Job får efter katastrofen, kan betraktas som ett slags "ersättning" för dem han förlorat, och att de därigenom blir vittne till oskyldigt lidande. ${ }^{4}$

Det framgår gång efter annan av den andra generationens texter att Förintelsen är en oskiljaktig del av deras identitet, trots att de inte själva genomlevt denna katastof. Den andra generationen bär med Bergers ord vittnesbörd om "the presence of an absence", 5 den är med andra ord "witness to memory", vittnen inte till själv händelsen utan till minnet av den. Fokus ligger av naturliga skäl på upplevelsernas återverkningar i föräldrarnas och deras eget liv och mindre på själva händelseförloppet. Den erfarenhet som gestaltas i texterna är hur det är att leva i skuggan av en händelse som man inte själv direkt upplevt, men som ändå så i grunden kommit att prägla det egna livet.

När det gäller den svenska Förintelselitteraturen tillhör Susanne Levin med sina båda första böcker Leva vidare (1994) och Som min egen (1996) kategorin författare ur den andra generationens överlevande. Hennes ungerskfödda mamma överlevde Auschwitz och Bergen-Belsen och kom till Sverige med de så kallade vita bussarna vid krigets slut. ${ }^{7-}$ Levins båda böcker bär undertiteln "Berättelse" och balanserar i likhet med så mycken annan Förintelselitteratur på gränsen mellan självbiografi och fiktion. De handlar om hur huvudpersonen Lea Louises barndom och vuxenliv präglas av det faktum att hennes mamma överlevde Förintelsen. Leva vidare, som skildrar Leas liv från barndomen i 1950-talets Uppsala till dess att hon blir vuxen och är i färd med att bilda familj, är berättad i tredje person och huvudsakligen kronologiskt, dock med enstaka tillbakablickar på moderns liv innan hon kommer till Sverige. I Som min egen, också den relaterad i tredje person, sker en regelbunden växling mellan två tidsplan: det ena handlar om den vuxna Lea och hennes tillvaro som maka, förälder till två från Latinamerika adopterade barn och yrkeskvinna, medan det andra följer Lea från sexårsåldern till dess att hon är vuxen, så att de båda tidsplanen möts i slutet av boken.

Den andra generationens erfarenheter gestaltar ocksa Suzanne Gottfarb, som dock inte själv tillhör denna grupp, ${ }^{8}$ i Systrarna Blaumans hemlighet (1987). I centrum för romanen står tre kvinnor: den drygt trettioåriga Mira Judith Blauman, hennes ensamstående moder Hanna Blauman samt dennas 
tvillingsyster Rosa, som båda hör till Förintelsens överlevande offer och som bott tillsammans efter att ha räddats till Sverige. Bokens nuplan är förlagt till 1980-talets Stockholm och de tre kvinnorna fungerar som berättare i var sitt avsnitt av varierande längd. Berättarsituationen medverkar till att komplicera det projekt som Mira föresatt sig att genomdriva: att ta reda på sanningen om vem hon egentligen är och skapa klarhet $\mathrm{i}$ vad som hände hennes moder och moster under Förintelsen. Det finns dock ingen överordnad, auktoritär berättarröst som rätar ut de frågetecken som ännu kvarstår vid romanens slut.

Syftet med denna artikel är att jämföra bilden av livsvillkoren för den andra generationens överlevande i Gottfarbs respektive Levins böcker. Som Berger påpekar kommer Förintelsen att utgöra en oskiljaktig del av deras identitet och han ställer vidare frågan: "What are these new types of Holocaust witnesses to do with an event not personally experienced?"9 . Dessa barn bär självfallet vittnesbörd om att deras föräldrar överlevde Förintelsen; de ger dem en röst och försöker förstå deras lidande. I det följande kommer därför intresset att fokuseras på huvudpersonernas jakt på föräldrarnas erfarenheter: de lyssnar uppmärksamt till överlevandes redogörelser - föräldrarnas och andras eller försöker lägga pussel med ledtrådar när föräldrarna inte är så meddelsamma. Vidare kommer jag att uppmärksamma barnens upplevelse att var bärare av sina föräldrars förhoppningar. Avslutningsvis kommer brottningen med den egna identiteten bland andra generationens överlevande att behandlas; dessa barn försöker bättre förstå vem de själva är i ljuset av föräldrarnas erfarenheter. Som Berger påpekar ligger det nära till hands för barn till överlevande att "understand themselves and their connection to the Jewish tradition in terms of their parents' Holocaust experience". ${ }^{10}$

\section{PÅ JAKT EFTER MODERNS UPPLEVELSER}

Centralt hos både Gottfarb och Levin är de två kvinnliga huvudpersonernas intensiva försök att rekonstruera och skapa sig en så klar bild som möjligt av vad deras respektive mödrar genomlidit under Förintelsen. Barn till överlevande har som Berger skriver "a compulsive need to learn about the Holocaust". ${ }^{11}$ Anledningen kan vara att de redan tidigt, $\mathrm{i}$ likhet med Mira och Lea, kommer underfund med att det saknas personer i deras omgivning: de släktingar som mördats under Förintelsen men som de flesta av deras jämnåriga kamrater har i livet. Man kan med Judith Beerman Zeligsons ord tala om de "stora tomma hål" som finns i familjehistorien som en förklaring till den kollekriva "skugga"12 som faller in i den andra generationens tillvaro. Det kan vara mostrar och fastrar, mor- och farbröder samt far- eller morföräldrar som saknas. 
Det finns dock stora skillnader när det gäller Miras respektive Leas möjligheter att genomdriva denna föresats, vilket ytterst har att göra med hur deras respektive mödrar har lyckats hantera sina traumatiska upplevelser under Förintelsen. Medan Mira får kämpa en ensam kamp för att skapa sig något slags föreställning om vad som hände modern under kriget, är det Leas mamma som själv beredvilligt berättar om sina upplevelser.

Anledningen till att Mira beslutar sig för att skriva ned berättelsen om sitt liv är att hon upplever att hennes egen identitet är oklar eller problematisk (mer härom i artikelns slutavsnitt). Efter en omskakande upplevelse då Mira tycker sig konfronteras med en kvinna som förefaller vara en exakt kopia av henne själv, en dubbelgångare, konstaterar hon:

jag skulle behöva ett andrum i tillvaron och använda den tiden till att försöka få något slags översikt över mitt hittillsvarande liv och därmed söka komma fram till vem jag innerst inne är; en klok person vid sina sinnens fulla bruk eller en galen människa som lider av paranoida föreställningar? Kanske bor dubbelgångaren i själva verket inne i min egen kropp? [-] För att försöka svara på alla dessa frågor har jag beslutat att nedteckna hela min levnads historia fram till dags dato, och det är därför jag nu böjd framför skrivmaskinstangenterna slagit på det svagt surrande elektriska ljudet och tänt lampan vid fönstret.

Skrivmaskinstangenterna som triumfatoriska trumvirvlar mot det ödsligt vita pappret och mitt liv startar (SBH:Ig f).

Miras mamma, liksom för övrigt hennes moster, medverkar genom sitt sätt att förhålla sig till att dottern finner det nödvändigt art ta befattning med det förflutna. Genom antydningar och halvkvädna visor har Mira kommit fram till att de båda systrarna har upplevt fasanfulla ting i Auschwitz som de bär på outplånliga minnen av. Miras önskan i barndomen att få se på skräckfilm kan inte Hanna förlika sig med: "Jag skämdes över mina morbida lustar när Hanna plågat såg ut genom fönsterrutan och tillade: Ja, ja, du har ju aldrig behövt uppleva skräckfilm på riktigt som jag. Hennes tankar gick till Auschwitz i Polen och mina blickar till hennes hud. Innanför det långa svarta klänningstyget doldes små blå siffror, osynliga för mina ögon under tyget men ständigt brännande mot hennes underarm" (SBH:24 f, 3I). Miras moster har också levt med strategin att inte ta befattning med det förflutna. Hon har isolerat sig och hyst en uttalad motvilja att ens med sin syster Hanna diskutera svunna tider, "att röra i gamla minnen" (SBH:272).

Mira lever i en värld av antydningar, vilket skapar en hel mängd frågor, bland annat om vad modern och mostern tvingats utstå $i$ Auschwitz och om andra släktingar, däribland mormor och morfar. Hur dog de? Varför? Hennes mamma och moster har som de uttrycker det "en gemensam tro på att det är för ditt eget bästa som du bör undanhållas vissa saker. Det finns sådant vi 
varken vill eller vågar berätta" (SBH:88). De lyckas härigenom skapa en nödtorftig jämvikt i sina egna liv som de framlever isolerade i sin våning med sammetsgardiner som håller dagsljuset på avstånd och försätter hemmet $i$ en ständig halvdager: "På golvet låg persiska mattor i mystiska slingermönster för att dämpa oväntat häftiga ljud, vilka kom de båda tunna kvinnorna att skaka och lägga sina långa fingrar som skydd över de utskjutande nyckelbenen. [-] Mina barnaögon måste ha utgjort en skärande kontrast till de båda fågelkvinnorna, som ruvade som olyckliga korpar från våningens mörkaste hörn, där de betraktade mig med sina pergamentsgamla själar" (SBH:29). Hemmet präglas i grunden av det faktum att systrarna inte bara är Förintelsens offer utan att de också är förlamade av sin erfarenheter, låt vara att en av systrarna driver en tandläkarpraktik. I sådana "victim and numb families" är det enligt Berger mindre troligt att föräldrarna berättar några detaljer om sina upplevelser. ${ }^{13}$

För att stilla sin nyfikenhet letar Mira nattetid rätt på systrarnas dagböcker och inser att den jämvikt som de nödtorftigt kämpar sig till på dagarna (moster Rosa sköter sin praktik och mamma Hanna hemmet; de lever ett visserligen ensamt men till det yttre "normalt" liv under iakttagande av de judiska traditionerna) under nattens drömmar förvandlas till plåga och kamp med smärtsamma minnen. Rosa skriver: "Stundtals ser jag ljuset som ett grått hopp vid horisonten, tänker kanske ändå, också jag, en ny chans, går och lägger mig efter en behaglig dag med en vag känsla av tillförsikt, då det knackar på min panna, och jag ryser i vetskap om att samme gamle objudne gäst åter vill in, den hatade maran, som är så förtjust i mig att han trots min avvisande hållning vägrar lämna mig ifred" (SBH:5o). Rosas i dagboken nedtecknade drömmar ger vaga antydningar om upplevelser under Förintelsen. Medan hon egentligen endast är en flicka, befinner hon sig tillsammans med systern på en järnvägsstation, vars namn innehåller den i sammanhanget olycksbådande bokstaven " $z$ "; in rullar järnvägsvagnar "förbommade med plankor" (SBH:ro4) där det råder stor trängsel.

Istället för att nöja sig med förhoppningen att modern och mostern en dag skall lätta på förlåten och berätta för Mira vad de faktiskt var med om under andra världskriget, söker hon sig till biblioteket och den litteratur av olika slag - mängder av vittnesmål och skildringar från överlevande - som behandlar Förintelsen. Med hjälp av dessa böcker börjar hon det mödosamma arbetet med att rekonstruera tvillingsystrarnas upplevelser och livsvillkor. I Förintelselitteraturen finner hon den kontext där hon kan placera in Rosa och Hanna.

Dessa fasansfulla nattliga strövtåg, som alla slutade vid koncentrationslägret Auschwitz plattform, ty där hade Rosas och Hannas resa upphört och en ny tagit sin början. De låsta boskapsvagnarna. Stanken från överfyllda urinhinkar. Syrebristen i de fullastade tågen. Människor som kvävdes stående hårt tryckta mot varandra. Utsikten genom fönsterhålen för 
dem som befann sig närmast. Skylten Auschwitz skriven med gotiska bokstäver, vars namn inte sade de resande någonting. Barnen som vätte sina uttorkade läppar med torra tungor. Hårda fotsteg i sanden utanför. Skrik, befallningar, piskslag. Köerna längs med spåret. SS-vakterna och chefsläkaren i nyputsade stövlar närvarande vid varje tågtransport, fruktad av alla. Den till utseendet oklanderlige Dr Mengelse. Urvalet. Den vänstra kön, destinerad till omedelbar död i form av gasning. Där stod åldringar, krymplingar, sjuka, klena samt kvinnor med barn under fjorton år. Åtminstone under ett visst skede av kriget, då arbetskraft fortfarande behövdes. Senare gasades alla. Den högra kön av arbetsdugliga män och kvinnor destinerade till svält, sjukdomar, hårt arbete, sömnbrist och tortyr i väntan på döden i någon av träbarackerna. Jag tänkte mig Rosa och Hanna, vid den tidpunkten bara tonårsflickor, anlända med ett av tågen (SBH:ro6 f).

Hennes sammantagna läsning resulterar i denna kondenserade bild av händelseförloppet och samtidigt av den mängd böcker om skeendet som Mira läst. Visserligen har hon nu skapat en ram för skeendet, men än återstår självfallet en mängd obesvarade frågor: anlände systrarna Blauman ensamma? varför undslapp de den vänstra kön?

För att skapa sig en bild av hur tvillingsystrarna sannolikt tvingades framleva sina dagar $i$ Auschwitz, tar Mira hjälp av två utanför romanens pärmar verkligt existerande böcker. Den första är författad av den överlevande läkaren Miklos Nyiszli och bär titeln Auschwitz, a doctor's eyewitness account (I960). Gottfarb låter Mira citera en längre passage där rutinerna $i$ utrotningslägret beskrivs, särskilt de ständigt återkommande så kallade "appellerna", då fångarna timme efter timme räknades och inspekterades.

Den allt överskuggande frågan för Mira är dock: "Av vilken anledning hade just Hanna och Rosa klarat sig" (SBH:IO7)? Varför hade inte de, i likhet med andra barn i deras egen ålder, placerats i den kö, som innebar omedelbar död? De två flickorna kunde inte rimligen utgöra någon attraktiv arbetskraft. Svaret finner hon i en annan redogörelse $\mathrm{i}$ bokform, som dock inte författats av ett överlevande offer, utan av Rudolf Höss, som under en period tjänstgjorde som högste chef i Auschwitz. I den tyska utgåvan av Höss självbiografi, som utkom i svensk översättning 1979 med titeln Kommendant i Auschwitz, sammanfattar författaren i nio punkter "SS-läkarnas verksamhet utom den ordinarie tjänsten inom koncentrationslägret Auschwitz" . ${ }^{14}$ Mira citerar detta avsnitt i sin helhet, vilket utgör en i sina detaljer förfärlig och makaber läsning. Men det är särskilt en passus hon fäster sig vid, eftersom den antyder vad systrarna Blauman gått igenom: " 'Experiment gjordes av Dr Mengele på tvillingforskningens område genom undersökningar av enäggiga judiska tvillingar' " (SBH:Ir2). Med hjälp av denna upplysning kan hon börja skapa sig en bild av det lidande som märkt systrarna för livet: "De två omtåliga [sic!] 
vita fåglarna, på pricken lika varandra, sönderkramade och utforskade av läderbehandskade fingrar tills blodet sakta föll från näbben och deras hjärtan hördes picka allt svagare. Aldrig mer ska ni flyga, friheten för alltid förlorad, nu inneslutna i er egen rädsla" (SBH:Ir2). Därmed tycker sig Mira ha funnit den nyckel hon så länge sökt för att öppna dörrarna till moderns och mosterns förflutna. Under en måltid vågar hon så äntligen ställa en direkt fråga, men reaktionen är så våldsam att hon på stående fot lovar att aldrig nämna namnet på den förhatlige läkaren Mengele: "Jag tystnade, ty Hanna hade stelnat i sin halvt uppresta ställning och tallrikarna flög från hennes händer över hela rummet [-]. Rosas ögonbryn var som två vassa spjutspetsar över den smala näsan. Tänkte hon hugga mig?” (SBH:II4). Modern får ett regelrätt sammanbrott, måste hjälpas i säng och nödtorftigt lugnas med tabletters hjälp.

Mira är åter hänvisad till Förintelselitteraturen för att få svar på sina talrika frågor. Det är än en gång hos Miklos Nyiszli som hon finner den information med vars hjälp hon han skapa sig en bild av moderns och mosterns tillvaro i Auschwitz. Den överlevande läkaren berättar om plågsamma experiment "in vivo": det rör sig om "blodtester, ryggmärgspunkteringar, utbyte av blod tvillingsyskon emellan samt en mängd andra undersökningar av tröttande och påfrestande natur". Därtill kommer de möjligheter till vad som med den perverterade naziterminologin benämndes "jämförande obduktioner" ( $\mathrm{SBH}$ : I2०f) av tvillingar, som mördats samtidigt på Mengeles order.

I slutet av romanen, i berättandets nu, beslutar sig Mira för att tvinga systrarna att en gång för alla ta bladet från munnen. Bland de häpnadsväckande ting som hon då får höra är att hon själv en gång hade en tvillingsyster, som kidnappades när moster Rosa promenerade med barnvagnen. Hanna märker att beskedet minst sagt innebär en chock för Mira och anmärker då att det var bäst som hände. Med hänvisning till sina egna erfarenheter hävdar hon att tvillingskap "kan vara ett fruktansvärt lidande. Hon sliter upp sin klänning och blottar sitt nakna bröst. Ett långt ärr löper utmed hela bålen. - Se, väser hon. Ett ärr från kriget. Auschwitz experimentbaracker. Enäggstvillingarnas Helvete. Jag var där. Jag såg. Jag deltog. Högen av tvillinglik. Lukten av deras brända ben. Knivar, blod, stank och de dödliga injektionerna rakt in i hjärtat" (SBH:308).

Alla dessa försök från Miras moder och moster att sopa det förflutna under mattan, att undanhålla Mira kunskap om vad de själva genomlidit, finner man inte någon motsvarighet till i Susanne Levins Leva vidare. Här upplyses Lea redan i samband med skolstarten om vad Förintelsen innebar för hennes mamma. Här görs inga försök att "skona" flickan, att begrava det förflutna i tystnad. Leva vidare inleds med några korta ögonblicksbilder från Leas relativt skyddade barndom i 1950-talets Uppsala. Hon leker bekymmersfritt i kvarteren kring Fyrisån. Tillvaron på gården omgärdad av skyddande husväggar är 
tämligen trygg: "Hennes glaskula är ett jättelikt öga som speglar hela gården. Den smeker henne, så rund och glatt $\mathrm{i}$ handen" (LV:Ir). Leas värld är överblickbar; här finns ännu inga dissonanser som stör hennes tillit till omgivningen. Ibland påminns hon om sin judiska identitet, som då hennes farfar, vars far flydde till Sverige undan judeförföljelserna i Polen under förra seklet, upprepar sin synpunkt att hon skall hålla sig "ifrån gojim" (LV:22). Grannpojkens nyfödda kattungar utgör ännu ett inslag i idyllen: "En liten kattunge att älska vill hon ha. I soffan hos grannpojken smeker hon de små runda magarna, de små mjuka huvudena, och de buffar på henne" (LV:II).

Som en blixt från klar himmel rämnar dock idyllen och förhoppningarna; döden tränger sig på. Stentrappans mörka blodfläckar vittnar om hur pojkens pappa avlivat kattungarna och nödtorftigt begravt dem: "Med en pinne petar han på den de lekt med och kelat med i går. Den lilla runda magen går sönder, rinner ut på gruset" (LV:I2).

Ondskan slår på detta sätt en kil in i barnets omedelbara och trygga förhållande till världen, men det är först när Lea börjar förstå vad hennes egen mamma varit med om som ytterligare en dimension fogas till den krackelerade idyllen. Tidigare har hon, gömd i en garderob, noterat hur de vuxna talar "lidandets språk" (LV:I3) på en blandning av tyska och jiddisch för att barnen ska förbli okunniga och inte utsättas för obehagligheter. Lea vet visserligen att hennes mamma är född i Ungern och att hon själv, till skillnad från de flesta av sina jämnåriga, inte har några morföräldrar.

I samband med att Lea ska börja skolan tar dock hennes mamma, som menar att man inte kan "sudda ut det liv, man har bakom sig" (LV:I44), bladet från munnen: "Nu får hon veta att de blev mördade med gas för att de var judar och att massor av judar dog på samma sätt i Ungern och i Tyskland och i Polen. Han som dödade dem hette Hitler. Det är så hemskt, för hon märker ju hur ledsen mamma är, även om hon inte gråter" (LV:28 f). Den "alldagliga" ondskan $\mathrm{i}$ form av de döda kattungarna får därmed en betydligt allvarligare underton när den i barnets förståelse kopplas samman med de förfärliga händelser som förbinds med namnet "Hitler" och vars följder mamman har börjat antyda för sin dotter: "I dunklet i tamburen med svagdrickskaggen ser Lea sedan Hitlers ansikte varje dag. Han som slog ihjäl de små katterna kommer och går som en skugga, alltid utan att tala med barnen. Hon vet. Hon har känt igen honom" (LV:3I). Det förflutnas hotfulla gestalter är påtagligt närvarande $\mathrm{i}$ den lilla flickans värld. Man kan jämföra med en passage ur andra delen av Spiegelmans Maus, där en vakt i ett koncentrationsläger pekar hotfullt med sitt gevär på den verklige författarens motsvarighet i serien, som utspelar sig i den amerikanska samtiden. ${ }^{15}$

Under det kalla krigets hotfulla era - året är 1960 - diskuteras i medierna risken för ett nytt världskrig och Lea, som just fătt veta vad hennes mamma 
genomlevt under förra världskriget, anar sig till vad en ny väpnad konflikt skulle kunna innebära: "Hon är mammas flicka. Likadan som hon, hör ihop med henne, bär på samma öde" (LV:74). Hon låter sig visserligen lugnas när mamma bedyrar att de är säkra på landet, men de uppseendeväckande många varor som mamma samlat samman i skafferiet talar ett annat språk. Grundtryggheten är rubbad.

Så kommer Leas barndom att utspela sig mellan hennes egen materiellt sett trygga tillvaro under de svenska så kallade rekordåren med ökande standard och sommarnöjen (se avsnittet "Pastoral", LV:57 ff) och mammas upplevelser under Förintelsen, som Lea efter hand făr en allt klarare bild av. "Mamma berättar så mycket om sin ungdom" (LV:50). Texten rymmer också förtätade skildringar av moderns långa år i Förintelsemaskineriet. På dryga två sidor skisseras först själva befrielsen:

Trehundrasextiofem morgnar reser sig det som en gång var en ung, nygift kvinna från sin brits. Hennes knotiga fingrar fattar om muggen som är fäst runt den tunna, tunna midjan, innan de rensar armhålorna på näve efter näve av löss. Febern bränner bakom ögonen, de stora, mörka, som möter nattens skörd av lik.

I högar ligger armar och ben, som körs bort på vagnar, kastas i diken, medan hon går förbi med sin mugg. [-] En morgon när hon vaknar har skriken tystnat. Alla tyska vakter är borta (LV:47).

Om läsarna tidigare i huvudsak fătt ta del av skeendet via Leas blick, återges här snarare moderns syn på skeendet: fokaliseringen skiftar tillfälligt från Lea till hennes moder. Denna skildring av moderns öde är som framgått ovan insprängd i redogörelsen för Leas barndom. På samma sätt infogas i skildringen av den sjuåriga flickans tillvaro två avsnitt - "Före" respektive "Efter" (LV:75-108) - som behandlar mammans tidigare liv. I det påföljande avsnittet "Främmande" är vi tillbaka på den plats i historiens kronologi där tillbakablickarna på mammans liv tar sin början: "Hon är sju år. De ligger på pappas säng, hon bakom hans rygg" (LV:IrI). Man kan notera att här liksom i mycken annan Förintelselitteratur är skildringarna av händelseförloppet i Auschwitz eller andra förintelseläger påfallande kortfattad eller saknas helt: boken rymmer inget avsnitt som $i$ analogi med de båda här diskuterade skulle kunna heta "Under". Detta intryck av en lucka i skildringen förändras inte av den tvåsidiga skildring av moderns befrielse som ovan diskuterats. Texten tiger på denna punkt i historien. ${ }^{16}$

Skildringen i avsnittet "Före" är fortfarande hållen i tredje person, men referensen är nu den lilla sjuåriga flickan Juci, som I950 ska bli mamma till Lea. Greppet, liksom likheten i ålder, understryker hennes starka identifikation med mammans öde. I det första av de båda avsnitten finns ytterligare en 
likhet mellan de båda sjuåringarnas tillvaro: även mammans barndom framstår som en skyddad idyll. Här finns ett överflöd av livets goda: "Wienerschnitzel på kyckling eller kalv fräser i stekpannan" och skafferiet rymmer ett väl tilltaget förråd av alla upptänkliga grönsaksinläggningar; "klasar av röda, blå och gröna vindruvor" hänger i rik mängd i taket. Tryggheten tycks total: "Fadern leker med flickans långa flätor" (LV:77 f), men den tilltagande antisemitismen i Ungern lägger hinder i vägen när hon och hennes lika unge älskade vill fullfölja sin utbildning. De båda gifter sig; maken försvinner i arbetsläger och själv deporteras Leas mamma tillsammans med sina föräldrar I944 när tyskarna tränger in i Ungern.

Idag lämnar Lujza, Sandor och Julianna Mandl ett liv bakom sig som aldrig mer skall återkomma annat än som minnen. [-] Hon passerar skolan, biografen, synagogan på väg till ghettot vid stationen. Godsvagnarna för dem snart mot Polen och Auschwitz.

Redan på vägen svimmar Sandor av batongslagen.

Mandl Luzja är fyrtiosex år och har ett stort operationsärr över magen.

När hon stiger ner på perrongen är hon redan dömd.

Mandl Sandor är svag och sjuk och femtiotvå år gammal, det avslöjar strålkastarna som riktas emot honom (LV:90).

Att Lea identifierar sig med moderns öde framkommer genom att de båda sjuåringarna på detta sätt skrivs samman så tätt. Här återskapas således inte endast moderns barn- och ungdom utan också de morföräldrar som Lea aldrig fått tillfälle att möta. Berättaren ger, som så ofta i texter om den andra generationens överlevande, med Bergers ord "voice for their survivor parents"17, men återskapar dessutom ytterligare en generations liv. En direkt parallell finns hos Gottfarb, där Mira citerar ur de minnen som hennes moster uppges ha nedtecknat.

En likartad vilja kan man ana i Leva vidare, där den verklige författaren i ett av bokens motton påpekar att den efterföljande texten är tillägnad de morföräldrar hon aldrig träffat:

Lujza och Sandor Mandl till minne.

Det här är den första minnessten jag lägger

på mina morföräldrars osynliga grav.

De mördades 1944 i Auschwitz

av tyska nazister.

Susanne Lousie (LV:5)

Lea är mycket angelägen att få veta mer om moderns liv under Förintelsen. De vidriga förhållandena - bristen på mat och personlig hygien - vänds till frågor om hur hon själv skulle ha reagerat på det som mamman utsattes för. 
Hennes livsmod och kampvilja imponerar på Lea: "Hur kunde mamma låta bli att stjäla? Hur kunde mamma låta bli att ge upp, när hon var så svag och sjuk, smutsig, hungrig och ensam?" (LV:I29).

Barnets behov att fa veta mer leder henne att söka svaret på sina frågor i litterära skildringar av Förintelsen. Hon fördjupar sig naturligtvis i Anne Franks dagbok, där hon finner "tankar som liknar hennes" och kan identifiera sig med den holländska flickans öde. Vidare tar hon del av Zenia Larssons böcker. I båda fallen tycks det henne som om det är mamman som berättar, villket $i$ kombination med hennes egen intensiva inlevelse leder till att mor och dotter "är så nära varandra nu, när hon vet att hon och Tommy är allt mamma har" (LV:I29).

Det utvecklas under Leas tidiga barndom en stark förbundenhet mellan mor och dotter, detta i kontrast till motsvarande förhållande i Systrarna Blaumans hemlighet, där Mira och modern aldrig möts på riktigt. I Levins Leva vidare gör modern dottern till sin förtrogna, hon lättar sitt hjärta för henne, hon gör "dottern till en väninna eller kanske till den lillasyster hon aldrig haft" (LV:I56). Flickan kan och har hört moderns berättelser, men tröttnar inte på att lyssna på dem igen: " 'Det luktar som din första man. Som Löwy Ferenc.' Då ler mamma emot henne och biter sig i underläppen. 'Har jag sagt det?' 'Ja, förra gången vi var här. Hans rock och väskorna han sydde luktar som det gör här inne. Jag minns också att du sade att du fick skor av din moster Nusika." " (SME:20). Lea lyssnar mycket ivrigt till allt mamman har att berätta. Hon har för övrigt en liknande intim eller förtrolig relation till sin egen dotter Amanda särskilt på romanens slutsidor; där hon t.o.m. säger att dottern är hennes mamma!

Vetskapen om att moderns hela familj utplånades under Förintelsen bidrar till att Lea själv också är så fästad och bunden vid modern. En av anledningarna är att hennes mamma är framställd som en stark personlighet som med livskraft och överlevnadsvilja, entusiasm och livsenergi, drar in dottern i sina sammanhang och till en början blir till hennes förebild. Med frustande energi "anpassar hon sin ungerska recept till familjens smak och öser med råge upp på barnens tallrikar, för att försäkra sig om att aldrig någonting skall kunna fattas de små" (LV:I8). Med sina ungerska väninnor för hon glada och uppsluppna samtal och "så skrattar hon så högt. Skrattet kommer bubblande långt inifrån henne ut till dem som sitter på golvet vid sina leksakshästar och dockor. Så snart Lea făr en låtsastelefon, härmar hon sin mamma på ungerska" (LV:46). Med tillfredsställelse betraktar modern sin dotter och är nöjd med vad hon ser: " 'Du har en så genomgjuten kropp, Lujzika! Ja, det har Tommy med. Det syns att ni är friska och starka. Det skall du veta att om jag själv inte varit så välbyggd, hade jag inte överlevt kriget. Då hade jag inte blivit utvald till arbetslägret. Då hade jag fått dö med så många andra, med sjuka, ofärdiga ... Pappa är stor och stark och full av liv, därför är ni också så livsdugliga. Tack och lov för det!' " (SME 4r). 
Kontrasten är avgrundsdjup mellan denna bild av en moder frustande av liv och den till följd av Förintelsen skröpliga och sköra modern, som balanserar på gränsen till sammanbrott i Systrarna Blaumans hemlighet. Miras mamma lider varje vår av en förlamande depression:

hon låg i sängen ända till lunch med sina smala vita händer vilande på täcket och stirrade ut genom de grårandiga fönsterrutorna. Små dammkorn dansade runt $\mathrm{i}$ hennes sovrum. Sedan hasade hon sig runt $\mathrm{i}$ tofflor och svart morgonrock, smekte pianotangenterna i vardagsrummet och ställde sig bakom sammetsgardinen. Hennes ansikte var mycket blekt, och hon hade blå skuggor under ögonen. [-] Hennes naglar var korta och avbitna. Hon var så tunn, så långt borta, overklig och omöjlig att röra vid. Mina frågor fastnade som vanligt i strupen ( $\mathrm{SBH}: 39 \mathrm{f})$.

Fram tonar bilden av en karaktär som är i det närmaste död i livet. Här finns inget av den varma samhörighet och frustande livsvilja som möter hos Levin. I systrarna Blaumans dystra våning råder ständig tystnad. Gottfarb skriver: "Vi var som ett tunt snöre, hoplänkade i vår bräcklighet med samma ritualer och samma historia men utan synlig kontakt med varandra" (SBH:4I).

När Lea i Leva vidare blir äldre och behovet av frigörelse växer sig starkare visar det sig allt svårare för henne att hălla fast vid denna grundmurade förbundenhet med modern: konflikter med anledning av alltifrån frisyr till klädval leder till att Lea också får svårt med moderns smärtsamma erfarenheter. Även i detta läge blir litteraturen en framkomlig väg och en av hennes starkaste läsupplevelser är Elie Wiesels självbiografi Natten:

Hur många böcker om Förintelsen har hon redan läst? Men ingen som denna. Ingen.

Hon känner naturligtvis igen detaljerna från mammas berättelser och andra vittnesmål hon läst och ändå är allt nytt igen. När mamma berättar orkar hon inte lyssna, vill hon inte höra. Det är svårt att tänka sig att hennes mamma som hon irriterar sig så mycket på, har varit med om så ohyggliga saker. Sin mamma borde hon naturligtvis älska och värna som en martyr och ett helgon. Men hon kan inte. I farfars soffa älskar hon i stället förbehållslöst den lille Elie som växer upp i förintelselägret, som lever sitt vuxenliv i USA. Han är på så lagom avstånd från henne och ändå så förunderligt nära (LV:204).

\section{FÖRÄLDRARS FÖRHOPPNINGAR}

Hos både Gottfarb och Levin knyter Förintelsens överlevande offer starka förhoppningar av olika slag till sina efterkommande. Det gäller för det första att barnen skall prestera sitt yttersta i skolan och skaffa sig en god utbildning. 
Miras framtid i Systrarna Blaumans hemlighet är långt ifrån hennes privata angelägenhet, utan något som inte endast modern utan även mostern har synpunkter på. Under ett allvarligt samtal, efter det att Mira under ett år studerat franska i Paris och därvid slagit sig lös, förtkunnar moster Rosa med sträv röst "som domare i en sorts domstol av högre natur, där ingen tvekan råder mellan rätt och orätt" att systerdottern "ska" bli läkare. Därmed blir Mira inte beroende av någon i framtiden och kommer fortsättningsvis att kunna leva på den standard som hon vant sig vid: "Det ger status, du kan rå dig själv, specialisera dig inom ett område som intressetar dig samt inte minst hjälpa människor i nöd, vilket i allmänhet är självtillfresställande [sic!]” (SBH:89 f). Den tjugoåriga flickan protesterar inte utan efterkommer framgångsrikt uppmaningen.

Även Lea i Leva vidare blir snart varse att hon är en individ som det knyts alldeles speciella förhoppningar till. När hennes första betyg innehåller ett enda $A B$ är pappans lakoniska men talande kommentar "Dåligt!" (LV:II5). Mamman, som själv inte förunnats möjligheten att studera, präntar med en tydlig referens till sitt eget öde in i dottern att det enda som inte kan tas ifrån en är det man en gång lärt sig. Skolframgångarna är också, menar pappan, ett sätt för henne att bli erkänd och väl sedd även utanför familjekretsen: "Kom ihåg att för en jude gäller det alltid att vara litet bättre än de andra, om han skall bli accepterad" (LV:II6). Lea väljer lärarbanan och ådagalägger en stor omsorg när det gäller att möta sina elever och utmana deras nyfikenhet. Man kan notera att både Mira och Lea väljer att utbilda sig för verksamhet $\mathrm{i}$ traditionellt "vårdande" yrken. Detta är enligt Berger vanligt förekommande för karaktärerna i de verk av andra generationens överlevande som samlats i en amerikansk antologi. Bland gemensamma drag hos dem finner han "a 'heightened sensivity to suffering' that eventuates in the fact that many children of survivors enter helping professions such as medicine, psychiatry, psychology, social work, and teaching". ${ }^{18}$

En annan förväntan som tidigt inplanteras i Lea och som också kan förstås mot bakgrund av att hennes egen mamma är en överlevande som förlorat hela sin familj under Förintelsen har med barn att göra: "För det har mamma lärt henne att den som inte har barn är en fattig människa. Barn är rikedomen i livet" (LV:42). Namnet "Lea" innebär, som redan Siv Illman påpekat i en recension av Leva vidare en "önskan att bli mor" ${ }^{19}$. Anknytningen till den gammaltestamentliga kontexten markerar också föräldrarnas - särskilt moderns naturligtvis - förhoppning att dottern skall skänka dem flera barnbarn. Lea födde ju som vi minns sex söner åt Jakob (I Mos. 29-30).

Att barn berikar livet är dock inte hela sanningen. Barnafödande framstår i det närmaste som en plikt. Tidigt inplanteras i Lea att hon som kvinna har ansvar för släktens fortlevnad. Detta framkommer redan i beskrivningen av hur modern ger liv åt Lea, som representerar något utöver sig själv, eftersom 
hon "kommer till världen i stället för de som brann upp i helvetet hon (=modern, min anm.) just sluppit ur" (LV:IO2). Moderns prestation består i att hon fogar "en ny länk till evigheten genom sitt sargade underliv" (LV:IO3). Att föda barn innebär en akt av motstånd, ett sätt att trotsa dem som ville utrota det judiska folket: " Barnen. Och barnbarnen, de som är det nya livet, de som är segern över döden, över dem som velat utrota och förgöra dem alla [—] Det hemliga vapnet till seger över dem som vill förinta hennes släkt är livmodern: livsrummet dolt $i$ hennes inre" (LV:2I4 f).

Redan innan hon som 23-åring gifter, skapar moderns förlossning i samband med Leas egen födelse, panikkänslor hos dottern: "Ångest. För att inte kunna fullfölja det som är hennes enda verkliga uppgift på jorden. Ångest." (LV:207). Efter att till sin förvåning ha blivit gravid utan svårighet, kommer så besvikelsens stund när missfallet är ett faktum: "Ur henne sipprar bland den röda vätskan all hennes längtan, alla hennes drömmar, all hennes kärlek. Hur mycket hon än önskar, ber och hotar förmår hon inte ändra någonting $i$ sitt öde" (LV:209). Lea tenderar att uppfatta barnlösheten som ett straff (SME:138). Ställd i relation till moderns kamp för överlevnad ter sig Leas oförmåga att i motsats till sin gammaltestamentliga namne ge liv åt en ny generation desto fatalare:

"Gud överge mig inte nu! Gud hjälp mig! Straffa mig inte". För sveket mot föräldrarna, mot folket, mot det som är hennes plikt framför alla andra - att låta livet gå vidare, föra släkten framåt, för de dödas skull.

"Varför skulle annars mamma överleva? Hjälp mig käre, gode Gud".

För varje missfall, för varje utebliven graviditet, blir hon allt mer medveten om att hon aldrig kommer att kunna föra det judiska arvet vidare. Mammas kamp för överlevnad, i lägren och här i Sverige, hennes våndor vid Leas egen födelse, var ett lidande utan mening och belöning.

För nu skall allting ta slut (LV:209).

Ett likartat dilemma plågar Leas femtonåriga dotter Amanda, som till följd av sin hjärnskada själv inte tror sig om att kunna ta ansvar för egna barn.

Berger påpekar att det bland många ur den andra generationens överlevande finns en helig plikt att föra familjen vidare: "I have a sacred duty to have children". ${ }^{20}$ Plikten att föda barn och den egna oförmågan leder till att Lea och hennes make Lars adopterar två barn från Latinamerika, som blir "Som min egen" (SME:Io).

Paradoxalt nog innebär Leas oförmåga att föda barn en länk, inte framåt men väl bakåt. Denna "brist" förbinder henne med den mormor hon aldrig träffat: "För nu minns hon. Mormor Lujza. Sammanväxningarna. Professorn. Gåslevern. Det stora ärret. Hon ser ner mot bandaget på magen. Äntligen har hon en länk till mormor!” (LV:2I7). 
Hanna Blauman i Gottfarbs roman uppfattar det i det närmaste som ett mirakel att hennes av döden märkta kropp kan "frambringa liv" samtidigt som den nyfödda och växande dottern förstärker hennes egen bräcklighet och inte förmår skingra "skuggorna från skeletten i massgravarna" (SBH:34). Den enda anledningen till att hon framhärdar och kämpar sig kvar i livet är att dotterns existens innebär ett sätt för förlorade familjemedlemmar att leva kvar: "De ska alla leva vidare i detta barn. Mitt hjärta blöder av medlidande med den lilla stackaren som snusar så tryggt under det vita sidentäcket. Hur ska du orka bära detta blodstyngda arv i din spädbarnskropp. Men jag kan inte bevara dig från din bakgrund" (SBH:35).

När hon blir äldre får Mira inte sällan höra om den andra förhoppning som knyts till henne i egenskap av andra generationens överlevande: att hon ska gifta sig med en judisk man och så föra det judiska arvet vidare (SBH:42). Har hon något eget värde som individ eller är det uteslutande hennes uppgift att "sona deras lidande? Skulle jag hämnas deras oförrätter?" (SBH:II5). Man kan notera att Mira själv knyter likartade förhoppningar till sin son Joshua: "Ty han är levande och varm. Han är begynnelsen till något och början är alltid så mycket bättre än slutet. Han har Paradiset inom sig" (SBH:158F). En annan slående likhet mellan moder och dotter är att också detta barn har en fader som är ganska okänd, en städare av israeliskt ursprung som Mira handlöst kastar sig i armarna på (SBH:I4O).

\section{Kampen MED DEN EGNA IDENTITETEN}

Hos både Gottfarb och Levin blir frågorna om den egna identiteten särskilt påträngande för de båda kvinnliga centralkaraktärerna. I Systrarna Blaumans hemlighet gestaltas Miras försök att komma underfund med hur hon personligen påverkats av det faktum att de båda kvinnor som så i grunden satt sin prägel på hennes uppväxtmiljö hör till Förintelsens överlevande offer. Det finns sidor i hennes personlighet som hon själv finner besvärande och som hon kopplar samman med sin mycket speciella uppväxtmiljö.

I Leva vidare och Som min egen gestaltas också kampen med den egna identiteten. Här gäller frågan hur Lea och hennes barn ska förhålla sig till judisk tro och judiska traditioner. Vad innebär det att ta sin judiska identitet på allvar $\mathrm{i}$ det dagliga livet, här och nu?

Miras behov att i skrift formulera sin egen identitet skall för det första ses mot bakgrund av att hon växt upp i ett hem i rekordårens Sverige där man strängt iakttagit de judiska traditionerna och högtiderna: "På fredagskvällarna firade vi sabbat. Rosa tände ljusen i silverkandelabrarna och läste en välsignelse på hebreiska. Vi åt hönssoppa ur beigefärgat porslin med guldbård, bröt challabröd som doppades i gehackte leber och tuggade i oss kokt höns med ris 
och currysås samt fruktsallad” (SBH:30). När Mira börjar skolan och möter jämnåriga icke-judiska kamrater konfronteras hon med en helt annan kultur och detta kulturmöte aktualiserar frågan om den egna identiteten, vilken hon förut inte haft anledning att fundera över: "Jag förstod inte hebreiska och endast ett och annat uttryck på jiddisch, medan det svenska språket låg väl i min mun. Ofta grubblade jag över min tillhörighet. Vår våning på Karlbergsvägen var som en egen värld fylld av dunkla minnen och judiska seder. [-] Var skulle jag placera mig. Ute eller inne? Hel eller halv? Ta avstånd eller omfatta det ena av de två alternativen till fullo? Eller leva med min inre splittring?" ( $\mathrm{SBH}: 4 \mathrm{I} \mathrm{f}$ ).

Miras brottning med den egna identiteten ser hon själv som ett resultat av att hon är barn till en överlevande: "Fick det min egen livskraft att hämmas? [-] Är det därför jag idag inte är tillräckligt levande för att kunna älska en vuxen människa? Var det för mig ett brott att växa till en livsstark människa, ett brott mot dem som likt skelett skramlade i våningens mörker?” (SBH:3I). Sina svårigheter att upprätta och kvarhålla djupa och bestående relationer till personer i sin omgivning kopplar hon samma med erfarenheterna i en uppväxtmiljö präglad av två individer med ett oförlöst förhållande till sina upplevelser under Förintelsen. När hon är i Paris avverkar Mira raskt en rad relationer och under sin utbildning till läkare går hon upp i sina studier och i ett rastlöst festande: "Jag skiftade älskare och skaffade väninnor. Ändå deltog jag aldrig på allvar” (SBH:I34). Hon deltar inte, utan spelar ett spel, där det viktiga blir att upprätthålla distansen till sin omgivning: "Ingen anade att den som var jag tassade tyst på avstånd vid dikeskanten för att vid minsta tecken till oro snabbt kunna gömma sig" (SBH:I34).

Hon gifter sig med en läkarkollega helt enligt det sociala spelets regler, men ganska snart mattas förhållandet och makarna blir allt otydligare för varandra: "Hur hade det kunnat bli på detta sätt? Var det min kyla som förintat honom tills han osäker och blyg inte längre syntes? Var han så rädd för sin hustrus tydliga avståndstagande attityd att han i ren självbevarelsedrift förvandlade sig till en skugga. [-] När allt kom omkring skilde sig inte min nya situation alltför mycket från de förhållanden som rått under min uppväxttid på Karlbergsvägen" (SBH:I37). Under sin tid i Auschwitz hade systrarna Blauman upplevt saker "som fått till effekt att hela deras syn på mänskligheten och tillvaron i stort totalt förändrats, och denna inställning till livet har de indirekt och glimtvis steg för steg överfört till mig. I hur hög grad är jag påverkad? Har jag en egen fri vilja? Väljer jag själv mitt betraktelsesätt eller styr Auschwitz SS-vakter även mitt öde? De flesta frågor har förblivit obesvarade" (SBH: Io9 f). Det är systrarnas förhållningssätt - ytterst en konsekvens av deras lidanden under Förintelsen - som gjort Mira till den skygga varelse hon uppfattar sig som. Det faktum att tvillingsystrarna levt så isolerade har bidragit till 
att Mira blivit alltmer avskild från sin omgivning:

Jag såg nu klart hur Hannas och Rosas väsen trängt in i mig, förgiftat allt det som var levande därinne och förvandlat mig till en skygg och oåtkomlig varelse. [-] Hålla sig dold. Inte lita på någon. Genomstungen av deras arv. Deras erfarenheter, aldrig klädda i ord, överförda till mig hud mot hud, por mot por, andedräkt mot andedräkt. Jag blev en del av deras väsen. Lärde mig av deras genomlevda kunskap att aldrig lämna en blotta, akta mig för piskrappen, inte synas, inte höras, vara försiktig. Ikläda mig offrets roll men hålla mig utom synhåll för bödelns blickar (SBH:I23).

Mira framställs som en utanförstående: hon lever visserligen men deltar inte på allvar i livet. Hon är en voyeur som skyddad betraktar omvärlden på avstånd. I takt med att hennes kunskap om vad modern och mostern tvingats genomlida ökar, får hon också perspektiv på sitt eget förhållningssätt; hon beskriver sig i stunder av svartsyn som en "grå skugga [...] iakttagen av ingen men själv iakttagande alla" (SBH:I23). Hennes hobby - fotografering - framstår som symbolisk i sammanhanget. Med hjälp av kameran kan hon frossa i det "indirekta seendet av andra människor" (SBH:I38). I skydd av kameran betraktar hon omvärlden och lever därmed sitt liv endast indirekt via de fotografier som ersätter hennes direktkontakt med människorna och världen.

Den andra aspekten av Miras kamp med identiteten utgörs av det faktum att hon aldrig med säkerhet får veta vem hennes far är. Då hon i yngre skolåldern utvecklar en mängd fantasier kring sin okände far och gång efter annan enträget ber modern att berätta om honom, reagerar denna alltid på samma sätt: "med plötsligt uppkomna fysiska krämpor som migrän, hjärtklappning och andnöd. Med tunn röst bad hon mig ödmjukt att inte plåga henne med minnen från det förflutna och avslutade alltid det korta samtalet med samma mening: - Det enda jag kan säga dig är att din far är en judisk man" (SBH:27).

När Hanna själv berättar om den period i sitt liv då hon för en kort tid var tillsammans med den man som är Miras pappa, demonstrerar hon en likgiltighet gränsande till ovilja när det gäller att ta befattning med sitt förflutna:

Vad som hände med Miras far minns jag inte. Jag har för mig att han lämnade Sverige utan att ha en aning om vad som hade skett. [-] Eller var det inte så det gick till? När jag tänker närmare efter är jag inte alls säker på saken. Men vad spelar det för roll idag. Många skeenden i mitt liv är höljda i dunkel och lika bra är det. Det finns säkert en mening med mina minnesförluster såväl som med allt annat här i livet. Skönast är det outgrundliga, ty då får livet fler dimensioner än de få futtiga som går att påvisa med vetenskapliga metoder (SBH:202). 
Hon vill inte längre veta, vilket framgår tydligt i romanens slutavsnitt där Mira anställer en uppgörelse med modern och systern för att få fram sanningen. Tidigare har hennes moder kallat den okände fadern för Erwin från Budapest, men nu uppger hon att han heter Alter Perlman och kommer från Litauen. När Mira tillfreds med svaret just skall bryta upp, kommer modern med ännu en version. Faderns namn var varken Erwin eller Alter, utan Jurij, en man från Ukraina (SBH:3II)!

Suzanne Gottfarb skildrar i sin bok Miras försök att komma tillrätta med och i någon mån återskapa eller stärka sin identitet. Hennes strävan är att laga eller återställa jaget. Denna strävan kan jämföras med begreppet "tikkun", som i den kabbalistiska föreställningsvärlden innebär ett försök att genom handlingar återställa eller göra helt det som slagits i spillror. I enlighet med den lurianska kabbalistiska föreställningsvärlden, vilken är en viktig kontext $\mathbf{i}$ Gottfarbs bok men framför allt i Susanne Levins romaner, existerar inte det fulländade $\mathrm{i}$ det förflutna eller i det tillstånd som föregick skapelsen, utan i framtiden. ${ }^{21}$ Bakgrunden till denna tankegång sammanfattar Levin i Som min egen: "I begynnelsen var oändligheten, i begynnelsen var Gud. Då var också tzimtzum, när Gud drog sig samman inom sig själv för att låta världen skapas ur tomhet. Och Guds ljus strömmade in i tomheten och skapelsens kärl. Men några av de kärl som innehöll himlaljuset brast och de gudomliga gnistorna förlorade sig ner i ondskans rike" (SME:I63). Detta är orsaken till den strävan efter att återställa eller laga det brustna - "tikkun" - som är en så central tanke i den lurianska kabbalan. Mira i Syskonen Blaumans hemlighet söker vad man kan beskriva som en "tikkun atzmi (mending or repair) of the self", vilken är en av de "two distinct Jewish paths" som Berger menar finns i texter av den andra generationens överlevande. ${ }^{22}$

Men Miras ambition att finna sanningen om sig själv för att på så sätt "laga" sig själv är inte alldeles okomplicerad. Efter att ha avslutat sin berättelse, beger hon sig hem till modern och mostern, i akt och mening att en gång för alla få reda på hur saker och ting hänger samman. Men även i denna stund är hon väl medveten om att "sanningen inte är enkel utan mångbottnad, dubbeltydig och svårtolkad [...]. Nej, om så bara ett endaste stoftkorn av sanning är sant, bör ändå all strävan riktas in på att finna detta flarn" (SBH:296). Miras konstaterande i Gottfarbs roman visar på den förbindelse mellan postmoderna insikter och "post-Holocaust worldviews" som Berger menar sig finna talrika exempel på i texter av den andra generationens överlevande. ${ }^{23}$ På romanens nuplan inser Mira att hennes berättelse om sitt liv är en konstruktion, att den måhända inte stämmer överens med sanningen i varje enskild detalj. Ändå menar hon att den är värdefull: "Är mina fantasier nedhamrade på skrivmaskinspapper natt efter natt, årstid in och årstid ut mindre värdefulla än till exempel det hus jag bebor? Mina egna berättelser fascinerar 
mig mer än det påtagliga trägolv jag stampar foten emot [—] Finns det någon objektiv verklighet? Jag ställer mig frågan än en gång och tänker på det olycksbådande mötet härförleden med kopian av mig själv" (SBH:I57). Hon frågar sig om hon någonsin kommer att kunna skriva sig fram till befrielse "från denna besvärjelse[-] Mitt liv; en ringlande kedja av frågor" (SBH:I58).

I Leva vidare och Som min egen gestaltar Levin huvudpersonens kamp med sin identitet $i$ ett mångkulturellt samhälle. Drivkraften bakom Leas handlande kan dock inte beskrivas som något slags "tikkun atzmi". Hon är snarare upptagen av frågan hur hon skall förhålla sig till sitt judiska arv och vilka konkreta följder detta făr i hennes dagliga liv.

Under sin tidiga uppväxt förs Lea, liksom Gottfarbs Mira, med fast hand in i den judiska tron och traditionen av sina föräldrar. Som liten skolflicka får hon en gång i veckan tillsammans med den jämnårige Jacob extra lektioner $i$ biblisk historia och judisk kultur. De făr bland annat lära sig mer om den "ende guden. Den som aldrig får nämnas vid namn. Den som tilltalas på hebreiska, med bokstäver som läses från höger till vänster, med bokstäver som pennan formar så långsamt och vackert den bara kan. Den kan man läsa om $i$ torahn" (SME:30). De judiska högtiderna sätter sin prägel på hennes uppväxt: hon făr exempelvis veta att på Jom Kippur minns man sina döda, även om barnen motas ut under en del av ceremonin.

Lea blir i likhet med Gottfarbs Mira efter hand varse att hon är annorlunda, att hon genom sin judiska härkomst avviker från omgivningen. Inledningsvis är hon för liten för att ens tänka på att dölja sitt påbrå, men hon görs snart av omgivningen uppmärksam på att hon genom att bland annat prata om sådant som "gefillte fisch" (LV:II3) signalerar sin hemmahörighet $i$ den judiska traditionen. Därmed börjar hon spela "dubbelspelet hemma och i skolan. Med varje termin blir hon skickligare att skilja de två flickorna åt. Det blir också mer och mer av skolflickan och mindre och mindre av pinchenflickan. Men ändå. Hon är annorlunda och känner sig främmande överallt. Tillsammans med barnen i judiska föreningen är hon svensk och med klasskamraterna judisk" (LV:I22).

Leas problematik - hennes utanförskap och identitetsproblematik - reflekteras av och förstärks genom beskrivningen av de problem som drabbar hennes dotter Amanda, som till följd av en lindrig hjärnskada (SME:86, 90) skrivs in i Omsorgsstyrelsen och hamnar på särskola. Flickan blir efterhand medveten om att andra betraktar henne som avvikande och plågas av frågor: "Vem är jag? Är jag den som vill vara som mamma och David och pappa eller den som alltid gör fel och är dålig på allt och aldrig hittar rätt sko och aldrig kan sätta mössan rätt och inte knyta skorna, aldrig någonsin knyta skorna fast pappa och jag övar varje dag hela sommaren. På sommaren leker jag i min sandlåda och gungar mellan äppelträden med min nalle. Vem är jag?" (SME:I27). 
När Lea i vuxen ålder beslutar sig för att medvetet odla sin judiska identitet, att vara "en riktig jude" (SME:I25) och fira alla judiska högtider, är bakgrunden att hon berörs så illa av en studentkamrats fördomar (näsor, huvudform) när det gäller vad det judiska egentligen består av. Pesach (den judiska påsken) och Simchat Torah (torahrullarnas fest) kommer hädanefter inte att gå obemärkta förbi. Lea odlar traditionerna i sin egen familj trots att hennes man är av icke-judisk härkomst och hennes båda barn är adopterade från det katolska Latinamerika. För att komplettera sin lärarutbildning studerar hon teologi och får då tillfälle att tränga djupare in i sitt judiska arv: "Tillsammans med rabbiner och poeter, med Maimonides och Jehuda Halevi, ger sig Lea Louise på resa genom Europa till Mellanöstern. Hon vandrar över den arabiska halvön och möter judenheten i medeltidens förskingring. Hon är där, så nära dem som inte längre finns på jorden" (SME:I64).

Att Lea beslutar sig för att leva som en "riktig jude" hindrar inte att hennes övertygelse gång efter annan sätts på prov i det mångkulturella samhälle hon lever i och att hon då och då gör avsteg från traditionen. Så tänder hon i adventstid ett ljus i den nyinköpta adventsstaken, "en sådan som bara gojim har" (SME:137), hon deltar i julfirandet i sin makes kristna familj och äter vidare mat som det inte anstår en "riktig jude" att konsumera. Frågan om traditionens bevarande ställs på sin spets i hennes egen mångkulturella familj när frågan om sonen Davids omskärelse aktualiseras. Lea är villrådig och maken säger: " 'Du som är så noga med din identitet, kan du inte förstå att han har lika stor rätt till sin som du till din. Han är av afrikanskt ursprung och kommer alltid att se sig som en svart colombian boende i Sverige. David är inte jude och kommer aldrig att identifiera sig som jude hur mycket du än omskär honom" " (SME:33).

I ett mångkulturellt samhälle problematiseras den identitet som är resultatet av nedärvd tradition. Leas son David utvecklar ett i sammanhanget symboliskt intresse för ympning av fruktträd och får fälla följande viktiga ord: "I mormor och morfars, farmors och farfars, pappas och din släkt, är Amanda och jag nya skott" (SME:IIo). Genom Leas båda barn görs det tydligt att identitet inte är resultatet av arv utan av val, att identitet är en kulturell konstruktion. Berger påpekar att "second-generation witnesses live in a postmodern era, a time when questions of memory and ethnic identity appear paramount. [-] affinities between postmodern and post-Holocaust worldviews. For example, the second-generation is concerned with the crisis of representation of memory as well as issues of cultural identity". ${ }^{24}$ När Lea berömmer dottern för att hon ber så fint över ljusen på sabbaten, deklarerar Amanda frankt: "Jag tänker bli som min mamma i Colombia i alla fall, inte som du. Katolik ska jag bli "(SME:I74, kurs. här). Hennes storebror David slår vid samma tillfälle fast att han inte tänker "bli jude som mamma" och att 
han inte märkt av att det finns en Gud! Detta kommer inte att hindra de båda syskonen från att hålla de judiska traditionerna vid liv: "Fast jag inte tror på någon gud alls och inte vill ha någon religion, för jag tänker inte bli katolik som du, så kommer jag att fira allt vi firar. Det vet jag redan. Tänk så synd det skulle bli om mina barn annars!" (SME:175).

Vad innebär det då för Lea att leva som en "riktig jude"? Vilka uttryck tar det sig i hennes dagliga liv? För Lea rör det sig mindre om fromhet, om tro och mer om vad hon gör, hur hon handlar. I rollen som gymnasielärare uppträder hon som engagerad, intresserad av sina elever och låter sig inte uppröras av deras försök till provokationer. Hon lägger ned stor möda på att försöka påverka deras attityder: "Hon tycker så mycket om de sju pojkarna. De är ju nästan som hennes barn! Tänk om de kunde fostras till att vara snälla mot varandra? Till en annan människosyn?” (SME:157). Men det finns gränser för hennes tolerans: då en manlig elev kommer till skolan iförd en t-shirt med en bild av Hitler på reagerar Lea starkt. När kollegor och rektor inte ser det som sin uppgift att reagera utan menar att det är upp till henne själv att göra det, söker hon upp eleven och förbjuder honom att någonsin ha den på sig i skolan. Det starkaste argumentet är samtidigt hennes mest personliga: "Du minns vad jag berättade om min mamma, eller hur?" (SME:I6r). Som andra generationens överlevande vägrar hon finna sig i att medverka till att nazismen făr göra sig synlig igen. För Lea gäller den beskrivning som Berger ger av den andra generationen: "behavoiral issues rather than explicit theological formulations are measures of Jewish identity". 25

Som ovan framkommit är kabbalistiska tankegångar en given kontext till Leas förhållningssätt. Hon besparar sig inte någon möda när det gäller att försöka ställa tillrätta vad hon uppfattar som missförhållanden i världen, att laga världen. Detta - "tikkun olam" - är den andra av de två judiska vägar som enligt Berger finns i texter av den andra generationens överlevande. ${ }^{26}$ Gnistorna från Guds ljus försvann ned i ondskans rike: "Sedan dess är det vår gemensamma strävan att återställa världen. Tikkun Haolam. Att laga den skapelse som gått sönder. Att befria de fängslade gnistorna från ondskan och föra dem åter till Gud. Och för att laga världen behöver Gud människan och människan behöver Gud och människorna behöver varandra" (SME:I63).

\section{Noter}

Hänvisningarna i parentes i den löpande texten avser Suzanne Gottfarbs Systrarna Blaumans hemlighet, Sthlm 1987 (SBH) samt Susanne Levins Leva vidare, Sthlm 1994 (LV) och Som min egen, Sthlm 1996 (SME).

I. Judith Beerman Zeligson, "Intill sjunde släktled? Om andra generationen", Auschwitz' skugga, red. Jaff Schatz \& Salomon Schulman, Stockholm/Stehag 1998, s. 59. 
2. Alan L. Berger, Children of Job. American Second-Generation Witnesses to the Holocaust, New York 1997, s. 19.

3. Berger, s. I.

4. Berger, s. 5 .

5. Berger, s. 2.

6. Berger, s. 20.

7. Marianne Steinsaphir, "Jag har inte sorg sedan jag började skriva", Läsfemina 1996:5, s. 26.

8. Ljiljana Dufgran, " Jag är inte bra på att känna mig halv' ", Judisk krönika, 2000:I, s. 9.

9. Berger, s. 3 .

1o. Berger, s. 3 .

II. Berger, s. 3 .

I2. Beerman Zeligson, s. 59.

I3. Berger, s. I4.

I4. Rudolf Höss, Kommendant $i$ Auschwitz (1958), sv.övers. Sthlm 1979, s. 225 f.

I5. Berger, s. 3.

16. Jfr. Anders Ohlsson, "Tal och tysnad i Förintelselitteraturen. Exemplet Zenia Larsson", Tidskrift för litteraturvetenskap 2000:2.

17. Berger, s. 3.

I8. Berger, s. I6.

19. Siv Illman, recension av Susanne Levin, Leva vidare, i Nordisk judaistik, vol. 16, no I-2, 1995, s. 131.

20. Berger, s. $2 \mathrm{I} \mathrm{f}$.

2I. The Oxford Dictionary of the Jewish Religion, ed. R. J. Zwi Werblowsky \& Geoffrey Wigoder, New York and Oxford r997, s. 426.

22. Berger, s. 4. "the perfection" (tikkun) of the world".

23. Berger, s. 9.

24. Berger, s. 9.

25. Berger, s. 25 .

26. Berger, s. 4 .

\section{SUMMARY}

This article deals with Swedish Holocaust literature by and about the secondgeneration witnesses, e.g. the children of survivors. It focuses on three novels: Suzanne Gottfarb's Systrarna Blaumans hernlighet ["The Secret of the Blauman Sisters"] (1987) and Susanne Levin's Leva vidare ["Live on"] (1994) and Som min egen ["As my own"] (I996). The Holocaust is an integral part of the protagonists' life and identity, although he or she has not personally experienced the event and in the article I examine three aspects of the conditions of life for the second-generation survivors. Firstly, their search for knowledge about their parents' experiences. Secondly, the burden of this generation to carry and fulfil the expectations of their parents and thirdly their struggle with identity in a multi-cultural society, where identity not only stems from heritage. 